University of Nebraska - Lincoln

DigitalCommons@University of Nebraska - Lincoln

Publications, Agencies and Staff of the U.S.

Department of Commerce

U.S. Department of Commerce

2011

Dramatic shifts in Hawaiian monk seal distribution predicted from divergent regional trends

Jason D. Baker

NOAA, jason.baker@noaa.gov

Albert L. Harting

Harting Biological Consulting

Tracy A. Wurth

Joint Institute for Marine and Atmospheric Research

Thea C. Johanos

NOAA

Follow this and additional works at: https://digitalcommons.unl.edu/usdeptcommercepub

Part of the Environmental Sciences Commons

Baker, Jason D.; Harting, Albert L.; Wurth, Tracy A.; and Johanos, Thea C., "Dramatic shifts in Hawaiian monk seal distribution predicted from divergent regional trends" (2011). Publications, Agencies and Staff of the U.S. Department of Commerce. 232.

https://digitalcommons.unl.edu/usdeptcommercepub/232

This Article is brought to you for free and open access by the U.S. Department of Commerce at DigitalCommons@University of Nebraska - Lincoln. It has been accepted for inclusion in Publications, Agencies and Staff of the U.S. Department of Commerce by an authorized administrator of DigitalCommons@University of Nebraska - Lincoln. 
MARINE MAMMAL SCIENCE, 27(1): 78-93 (January 2011)

2010 by the Society for Marine Mammalogy

Published 2010. This article is a US Government work and is in the public domain in the USA.

DOI: $10.1111 / j .1748-7692.2010 .00395 . x$

\title{
Dramatic shifts in Hawaiian monk seal distribution predicted from divergent regional trends
}

\author{
JASON D. BAKER \\ Pacific Islands Fisheries Science Center, \\ National Marine Fisheries Service, NOAA, \\ 2570 Dole Street, \\ Honolulu, Hawaii 96822-2396, U.S.A. \\ E-mail: jason.baker@noaa.gov \\ Albert L. Harting \\ Harting Biological Consulting, \\ 8898 Sandy Creek Lane, \\ Bozeman, Montana 59715, U.S.A.

\section{Tracy A. Wurth} \\ Joint Institute for Marine and Atmospheric Research, \\ 1000 Pope Road, \\ Honolulu, Hawaii 96822, U.S.A. \\ THEa C. Johanos \\ Pacific Islands Fisheries Science Center, \\ National Marine Fisheries Service, NOAA, \\ 2570 Dole Street, \\ Honolulu, Hawaii 96822-2396, U.S.A.
}

\begin{abstract}
Total estimated abundance of Hawaiian monk seals was just 1,161 individuals in 2008 and this number is decreasing. Most monk seals reside in the remote Northwestern Hawaiian Islands (NWHI) where the decline is approximately $4 \% / \mathrm{yr}$, whereas relatively fewer seals currently occupy the main Hawaiian Islands (MHI). It is widely accepted that the MHI population is increasing, although there are no formal estimates of total abundance, population growth rate or vital rates. This lack of information has hampered efforts to anticipate future scenarios and plan conservation measures. We present the first estimates of MHI monk seal survival and age-specific reproductive rates. Using these rates, a conservative estimate of current MHI abundance and a previously published stochastic simulation model, we estimate the MHI population growth rate and projected abundance trend. Analogous estimates for the NWHI are derived from a much richer data set. Estimated survival from weaning to age $1 \mathrm{yr}$ is $77 \%$ in the $\mathrm{MHI}$, much higher than recent NWHI estimates ranging from $42 \%$ to $57 \%$. Moreover, MHI females begin reproducing at a younger age and attain higher birth rates than observed in the NWHI. The estimated MHI intrinsic rate of population growth is 1.07 compared to a $0.89-0.96$ range in the NWHI. Assuming an initial abundance of 152 animals
\end{abstract}


in the MHI, projections indicate that if current demographic trends continue, abundance in the NWHI and MHI will equalize in approximately $15 \mathrm{yr}$. These results underscore the imperative to mitigate the NWHI decline while devoting conservation efforts to foster population growth in the MHI, where documented threats including fishery interactions, direct killing, and disease could rapidly undo the current fragile positive trend.

Key words: Hawaiian monk seal, Monachus schauinslandi, survival, reproduction, population growth rate.

Conservation biology is a forward-looking discipline that aims to affect a more positive future for imperiled species and ecosystems than present trends would otherwise allow. Conservation programs tend to be long-term, so that planning for plausible future scenarios is critical to success (Peterson et al. 2003). Moreover, several years may be required from the time a conservation issue arises until a suitable mitigation action can be implemented; by then, some new crisis may have become more pressing. In this context, the degree to which we can anticipate future realities will help avoid misplacing conservation resources.

These considerations are particularly germane in the context of conserving the Hawaiian monk seal (Monachus schauinslandi), a critically endangered species whose numbers are declining at a rate of approximately $4 \% / \mathrm{yr}$ from a 2008 total estimated abundance of 1,161 (Baker, unpublished observations). Most of the monk seals reside in the remote Northwestern Hawaiian Islands (NWHI), whereas relatively few occupy the main Hawaiian Islands (MHI) (Fig. 1). These two regions, NWHI and MHI, starkly differ in nearly every aspect relevant to monk seal conservation,

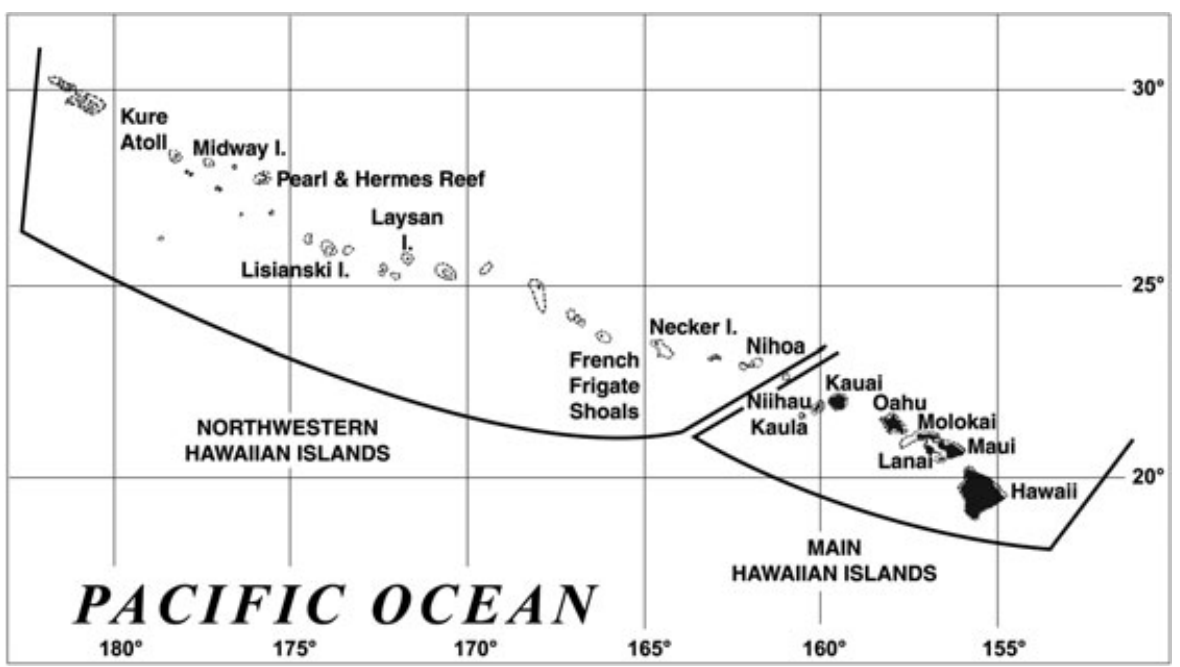

Figure 1. The Hawaiian Archipelago, indicating the main Hawaiian Islands and the primary Northwestern Hawaiian Islands subpopulations of monk seals at French Frigate Shoals, Laysan Island, Lisianski Island, Pearl and Hermes Reef, Midway Atoll, and Kure Atoll. 
including habitat, population status, threats, management, level of research, and allocation of conservation resources (Table 1).

In brief, the NWHI are part of the Papahānaumokuākea Marine National Monument, a vast marine protected area where coral reefs and associated fish populations are considered quite robust and fishing and other in situ human impacts have been minimized. In contrast, the MHI are characterized by a large human population and nearshore marine ecosystems severely impacted by physical alteration, heavy fishing pressure, and pollution. It seems somewhat counterintuitive that the monk seals in the MHI appear to be thriving (Baker and Johanos 2004), whereas the NWHI populations are declining, believed largely as a result of food limitation leading to low juvenile survival (Antonelis et al. 2006, Baker 2008). Baker and Johanos (2004) hypothesized that this situation might be explained by the MHI seals enjoying relatively low intra-specific competition (because the number of seals is still small) and low interspecific competition (because large predatory fish competitors such as jacks and sharks have been greatly reduced by fishing).

Hawaiian monk seals were listed as endangered under the U.S. Endangered Species Act in 1976, and the first Recovery Plan was completed in 1983 (Gilmartin 1983). At that time, seals were rarely seen in the MHI and the focus of the Recovery Plan was entirely on the NWHI. Indeed, there was no mention of the MHI in the 1983 plan. During the past $10 \mathrm{yr}$, monk seals have become an increasingly common sight in the MHI, and a recently published new Recovery Plan recommends management and research actions to foster the MHI population (NMFS 2007). This plan marks a formal recognition of the necessity to allocate more recovery resources to the MHI. However, it has been difficult to assess the present and, perhaps more importantly, the future conservation value of the MHI because basic information on the status and trends of MHI monk seals has been lacking.

In recent years, we have accumulated data from the MHI on individually identifiable seals either tagged or recognizable from natural marks. Here, we present updated minimum abundance information and provide the first estimates of survival rates and fecundity. Using a previously published simulation model (Harting 2002) incorporating these rates and some reasonable initial assumptions, we project future potential abundance in the MHI. This is compared to an analogous projection for the NWHI based on a much richer data set.

\section{Methods}

\section{MHI Data Collection}

Information on the MHI monk seal population was obtained primarily through a network of individual volunteers, volunteer groups, partner agencies, and directed efforts by the U.S. National Marine Fisheries Service. Many sightings were initially reported by members of the public using a phone number specifically for Hawaiian monk seal sightings. Information about sighting events was collected over the phone, including location, date, time, and description. Photographs, if available, were collected. Often, a member of an informal network of responders visited the site to confirm the sighting, attempted to read any tags, and photographically documented any natural or applied identifying marks. Researchers applied pelage bleach marks to aid identification, confirmed identities of sighted seals directly or by digital photographs, and determined size class and sex. In the event of a reported birth, 
Table 1. Comparison of factors relevant to conservation of Hawaiian monk seals in the Northwestern Hawaiian Islands (NWHI) and main Hawaiian Islands (MHI).

\begin{tabular}{|c|c|c|}
\hline & NWHI & MHI \\
\hline \multicolumn{3}{|l|}{ Habitat } \\
\hline Accessibility & Extremely remote & Highly accessible \\
\hline Physiography & Small atolls/islands & Large, high islands \\
\hline Area & $8 \mathrm{~km}^{2}$ & $16,000 \mathrm{~km}^{2}$ \\
\hline Shoreline length ${ }^{\mathrm{a}}$ & $80 \mathrm{~km}$ & $2,304 \mathrm{~km}$ \\
\hline Human population & $<100$ & $\begin{array}{l}1.3 \text { million residents, }>7 \\
\text { million visitors } \\
\text { annually }\end{array}$ \\
\hline Fish competitors ${ }^{b}$ & Abundant & $\begin{array}{l}\text { Relatively few, removed } \\
\text { by fishing }\end{array}$ \\
\hline \multicolumn{3}{|l|}{ Monk seal populations } \\
\hline Abundance & Approximately $1,100^{c}$ & $>113$ \\
\hline Trend & $4.1 \% / y r$ decline $e^{c}$ & $\begin{array}{l}\text { Unknown, presumed } \\
\text { increasing }\end{array}$ \\
\hline Threats $^{\mathrm{d}}$ & $\begin{array}{l}\text { Food limitation, shark } \\
\text { predation, male } \\
\text { aggression, } \\
\text { entanglement in } \\
\text { derelict marine debris, } \\
\text { sea-level rise }\end{array}$ & $\begin{array}{l}\text { Disturbance, disease, } \\
\text { direct fisheries } \\
\text { interactions, } \\
\text { intentional killing, } \\
\text { pollution }\end{array}$ \\
\hline \multicolumn{3}{|l|}{ Management } \\
\hline Fishing activity & Very little currently & $\begin{array}{l}\text { Intensive commercial and } \\
\text { recreational }\end{array}$ \\
\hline Habitat regulation & $\begin{array}{l}\text { Almost exclusively off } \\
\text { limits, by permit only }\end{array}$ & $\begin{array}{l}\text { No explicit habitat } \\
\text { regulation; }{ }^{\mathrm{e}} \text { ad boc } \\
\text { guidelines for behavior } \\
\text { around seals }\end{array}$ \\
\hline $\begin{array}{l}\text { Human interaction/ } \\
\text { disturbance }\end{array}$ & $\begin{array}{l}\text { Almost none, other than } \\
\text { by strictly regulated } \\
\text { permit holders. }\end{array}$ & $\begin{array}{l}\text { Unregulated. Disturbance } \\
\text { and interaction on } \\
\text { beaches and in water } \\
\text { common }\end{array}$ \\
\hline \multicolumn{3}{|l|}{ Research } \\
\hline Population monitoring & $\begin{array}{l}\text { Extremely thorough, } \\
\text { precise demographic } \\
\text { parameter estimates }\end{array}$ & $\begin{array}{l}\text { Relatively low. Minimum } \\
\text { abundance and some } \\
\text { tagging/resighting }\end{array}$ \\
\hline Foraging ecology & $\begin{array}{l}\text { Moderately } \\
\text { well-characterized }\end{array}$ & $\begin{array}{l}\text { Moderately } \\
\text { well-characterized }\end{array}$ \\
\hline Health/disease & $\begin{array}{l}\text { Moderately } \\
\text { well-characterized }\end{array}$ & $\begin{array}{l}\text { Moderately } \\
\text { well-characterized }\end{array}$ \\
\hline $\begin{array}{l}\text { Allocation of conservation } \\
\text { resources }\end{array}$ & Mostly allocated here & Little allocated here \\
\hline
\end{tabular}

\footnotetext{
${ }^{\mathrm{a} N O A A}$ (2001).

${ }^{\mathrm{b}}$ Friedlander and Demartini (2002).

${ }^{\mathrm{c}}$ Carretta et al. (in press).

${ }^{\mathrm{d}}$ National Marine Fisheries Service (2007).

eAlthough seals that land at some small State of Hawaii protected areas enjoy de facto reduction of human disturbance.
} 
the mother and pup were monitored closely until the mother departed at weaning. As soon as possible after weaning, pups were briefly captured, tagged with unique plastic flipper tags, measured (dorsal straight length and axillary girth) and sex was determined. In 2008, two aerial surveys of Niihau and Lehua islands were conducted at these otherwise inaccessible islands from a U.S. Coast Guard Dolphin helicopter, which flew slowly around the islands at low elevation $(<150 \mathrm{~m})$. Sighted seals were digitally photographed using a 300-mm image-stabilized lens.

\section{MHI Abundance and Survival}

MHI abundance was based upon the sum of the uniquely identified seals (mostly on the accessible islands) in 2008, plus the larger of the two aerial counts for Niihau and Lehua (corrected for seals already included as uniquely identified). To estimate survival, a sighting matrix was constructed for each known-aged seal (those tagged in their year of birth) for each year from birth to 2008. Estimates of survival and capture probability were generated using Program MARK (White and Burnham 1999). Patterns in Hawaiian monk seal survival have been well-characterized using the large database available for the NWHI (Baker and Thompson 2007). However, we recognized that the very limited sample size available for MHI monk seals would preclude characterization of temporal and spatial patterns. We therefore focused on characterizing age-related survival patterns, with all years and tagging locations combined. Thus, models with survival for sequential ages (weaning to $1 \mathrm{yr}, 1-2 \mathrm{yr}$, etc.), either combined or fitted separately, were compared using the small-sample Akaike's information criterion ( $\mathrm{AIC}_{\mathrm{c}}$, see Anderson et al. 2000). Because we knew that an organized MHI monk seal sighting network developed during the years of this study and reporting in general has been variable, we explored models with time-dependent probability of capture. Also, because pups are initially tagged only after weaning, the first estimated survival interval was determined from weaning to age $1 \mathrm{yr}$. This estimate was multiplied by the proportion of MHI pups known to have survived from birth to weaning from 1962 to 2008 to obtain a value for survival from birth to age $1 \mathrm{yr}$.

\section{MHI Reproductive Rates}

Because of limited data for calculating age-specific birth rates in the MHI, some inferences based on observed reproductive patterns in the NWHI were necessary. Harting et al. (2007) found that among three NWHI subpopulations, the highest age-specific reproductive rates were observed at the site (Laysan Island) where females also had the highest apparent growth rates. Because of the lack of quantitative agespecific morphometric data, Harting et al. (2007) used as a proxy for growth rate the proportion of females that had attained adult size at each age. For example, Laysan Island, where female seals attained adult size earliest on average, also showed earlier maturation and a higher peak reproductive rate. To compare MHI female growth, we analyzed the proportion of adult-size females by age in the MHI and NWHI using logistic regression analysis. Although size classification is a somewhat subjective exercise, consistency is achieved by a variety of means. New researchers are taught by seasoned field staff, and their classifications are checked and corrected. Staff is rotated among field sites to ensure spatial consistency. Field workers are directed to assess size class before reading tags to avoid the influence of knowing the ages when 
judging size. Finally, at the end of each field season, each seal is assigned a size class based upon the most common value assigned during multiple sightings that year.

Harting et al. (2007) fitted the following reproductive function to observed agespecific reproductive rates for NWHI seals ranging up to more than $25 \mathrm{yr}$ of age:

$$
m_{x}=\frac{a e^{d *[1-\exp (f x)]}}{1+\exp (b-c x)},
$$

where $a, b$, and $c$ govern the ascending phase of the reproductive curve ( $a$ determines the asymptote or maximum rate attained by mature females; $b / c$ gives the age at which females reach $50 \%$ of the maximum fecundity); whereas $d$ and $f$ jointly determine the onset and rate of senescent decline. For this study, there were relatively few known-age MHI females that ranged up to a maximum of $11 \mathrm{yr}$ old. Thus, we were only able to estimate the early, or ascending, segment of the MHI reproductive curve through age $11 \mathrm{yr}$. To obtain a full reproductive curve for the MHI, we fitted Equation 1 to a composite data set made up of MHI observations through age 11 and NWHI observations for older ages.

\section{NWHI Data Collection and Analysis}

Monk seal population biology research methods have been described in detail previously and a brief overview with key references is provided here. Annual research field camps have been conducted for approximately $2-5$ mo at the six main NWHI monk seal subpopulations since the early to mid-1980s (French Frigate Shoals, Laysan Island, Lisianski Island, Pearl and Hermes Reef, Midway Atoll, and Kure Atoll). Long-term marking and resighting of individual seals are the foundations of the demographic database. Abundance is determined by either total enumeration or closed capture-recapture estimates (Baker et al. 2006a, Baker 2004). Year 2008 estimates of monk seal abundance in the NWHI were used as the starting point for projections. Age-specific survival rates are estimated using field methods described in Baker and Thompson (2007). For this paper, observed survival in the NWHI was estimated using Jolly-Seber methods (Jolly 1965, Seber 1965), and the Siler competing risk survivorship model (Siler 1979, 1983) was then fitted to the observed rates, as described by Harting (2002). Given the small number of very old seals in the total NWHI sample, we fitted just one set of Siler model parameters governing senescence by pooling data for all sites. To reflect current population trends, our life table analysis and population projections for the NWHI used survival rate estimates only from 2006 to 2008 data rather than pooling data over all available years.

Age-specific reproductive curves were fitted for three of the NWHI subpopulations (French Frigate Shoals, Laysan Island, and Lisianski Island) in accordance with methods in Harting et al. (2007) using Equation 1. Rates for the other three NWHI subpopulations (Pearl and Hermes Reef, Midway Atoll, and Kure Atoll) were derived using a composite of the rates from the three measured sites, adjusted to best accord with the observed number of pups recorded at each site.

\section{Population Projections}

The monk seal stochastic simulation model (Harting 2002) was used to project each of the seven subpopulations (six NWHI sites and the MHI) forward $20 \mathrm{yr}$. 
The core of the simulation model conforms to a standard matrix projection, with the addition of migration among subpopulations, random sampling of vital rates from the estimated parameter distributions, and demographic stochasticity. For all sites, the mean and variance for the intrinsic growth rate $(\lambda)$ was derived from the random life tables constructed from 1,000 parameter-sampling simulations. For the projections, the starting distribution for each NWHI sites was based on the observed age-sex composition at that site. For the MHI, where detailed age and sex data are lacking, the initial abundance (for 2008 as described earlier) was allocated to age classes according to the stable age distribution associated with the fitted life table (using best fit curves to MHI survival and reproductive rates estimated as described earlier).

\section{RESULTS}

A total of 113 uniquely identifiable seals were documented in the MHI in 2008. This number is probably well below true total abundance because monk seal survey efforts in the MHI are far from exhaustive. Seals are probably undercounted to some degree at all the islands, but particularly at Niihau, Lehua Rock, and Kaula Rock. Niihau is privately owned, and access to the island is prohibited such that monk seal surveillance was limited to two aerial surveys in 2008. Lehua Rock and Kaula Rock are also quite inaccessible and, especially the latter, rarely surveyed. In August 2006, 15 seals were counted on a single small boat-based survey of Kaula Rock. Moreover, when complete surveys have been done, more seals are consistently seen at Niihau than at any of the other MHI (Baker and Johanos 2004). In 2008, 23 and 47 seals were counted on Niihau and adjacent Lehua Rock on the two aerial surveys, yet only one seal on the first survey and eight seals on the second survey could be categorized as unique based on features visible or photographed from the aircraft. We currently do not have corrections factors established to estimate abundance from MHI aerial surveys. Therefore, to obtain a conservative starting abundance for $\mathrm{MHI}$ population projections, we summed the total number of unique individuals identified (113) and the highest Niihau/Lehua aerial count minus the number of unique individuals identified on that count $(47-8=39)$, for a total of 152 seals. It is possible that some of the 39 unidentifiable seals on the aerial survey had in fact already been identified on other MHI in 2008, and would therefore be double-counted in our total of 152. This potential is impossible to evaluate because we lack information on the rate of interchange between Niihau and other islands. However, we think any such double-counting would be more than offset by undercounting animals throughout the MHI.

A total of 76 pups was tagged in the MHI during 1988-2007, and their resight histories through 2008 were the basis for estimating survival. Survival models focused on age variation, whereas survival was constrained to be constant over time and birth location. Age-specific survival rates are abbreviated as $\Phi_{i}$, with subscripts denoting age. Thus, $\Phi_{1}$ is survival from weaning to age $1 \mathrm{yr}, \Phi_{2}$ is survival from age 1 to age $2 \mathrm{yr}$, etc. Modeling results are presented in Table 2. Because Baker and Thompson (2007) found the greatest age variation in survival from weaning to age $5 \mathrm{yr}$, we began by fitting a model with constant survival for all ages $\Phi_{\text {constant }}$, then with separate survival parameters for the first year versus all older ages combined (denoted $\Phi_{1} \Phi_{2+}$ ), then with first year and second year survival rates distinct, all older seals combined (denoted $\Phi_{1} \Phi_{2} \Phi_{3+}$ ), etc. Allowing capture probability to vary by year improved 
Table 2. Survival estimation model results for 76 Hawaiian monk seals in the main Hawaiian Islands (MHI). Model column indicates which age-specific survival $\left(\Phi_{i}\right)$ and timedependent capture probability parameters $(p)$ were fitted. Parameter estimates from the second model in bold type were chosen for simulation modeling of the main Hawaiian Islands population.

\begin{tabular}{|c|c|c|c|c|}
\hline Model & $\mathrm{AIC}_{\mathrm{c}}$ & $\Delta \mathrm{AIC}_{\mathrm{c}}$ & $\mathrm{AIC}_{\mathrm{c}}$ weight & $\# \mathrm{Par}$ \\
\hline$\Phi_{1} \Phi_{\geq 2}, \not p 89-' 96,{ }^{\prime} 97-{ }^{\prime} 00,{ }^{\prime} 01-{ }^{\prime} 08$ & 319.3 & 0 & 0.468 & 5 \\
\hline 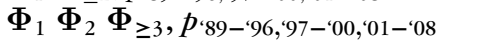 & 319.7 & 0.3 & 0.395 & 6 \\
\hline$\Phi_{1} \Phi_{2} \Phi_{3} \Phi_{\geq 4}, p \circ 89-' 96,{ }^{\prime} 97-{ }^{\prime} 00,{ }^{\prime} 01-' 08$ & 321.8 & 2.5 & 0.136 & 7 \\
\hline$\Phi_{1} \Phi_{2} \Phi_{\geq 3}, p_{\text {time }}$ & 334.6 & 15.3 & 0.000 & 23 \\
\hline$\left.\Phi_{1} \Phi_{\geq 2}, p_{\text {constant }}\right\}$ & 336.4 & 17.1 & 0.000 & 3 \\
\hline$\left.\Phi_{1} \Phi_{2} \Phi_{\geq 3, p_{\text {constant }}}\right\}$ & 337.3 & 17.9 & 0.000 & 4 \\
\hline$\left.\Phi_{1} \Phi_{2} \Phi_{3} \Phi_{\geq 4}, p_{\text {constant }}\right\}$ & 339.3 & 20.0 & 0.000 & 5 \\
\hline$\left.\Phi_{\text {constant }}, p_{\text {constant }}\right\}$ & 344.6 & 25.3 & 0.000 & 2 \\
\hline
\end{tabular}

model fits (e.g., Table 2, $\Delta$ AIC $_{c}=2.6$ for $\Phi_{1} \Phi_{2} \Phi_{\geq 3}, p_{\text {time }} v s . \Phi_{1} \Phi_{2} \Phi_{\geq 3}, p_{\text {constant }}$ ). Inspection of the annual fitted parameters suggested there were three periods with distinct capture probabilities (1989-1996, 1997-2000, and 2001-2008). Models fitted with three capture probability parameters representing these time periods resulted in considerable reductions in $\triangle \mathrm{AIC}_{\mathrm{c}}$ (Table 2). We recognize that fitting the reduced model after examining results of a previous model fit invalidates the use of AIC $_{c}$ for model selection. Yet, the survival estimates and their standard errors were nearly identical in the model with annually varying capture probabilities and the model with three time periods. We chose the latter for its parsimony. The observed pattern of fitted capture probabilities is consistent with trends in resighting ease and effort. For example, a single pup was born in 1988 and readily observed every year through 1995, resulting in a high estimated capture probability during the first set of years. During 1996-1999, nine pups were born (2-3 per year on various islands). Little effort was mobilized such that capture probabilities were relatively low. Finally, the increasing presence of seals in the MHI resulted in the development of a rather extensive volunteer monk seal protection effort, the activities of which included documenting and reporting seal identities. Thus, capture probabilities increased since 2000.

Support for the top three models (Table 2), which had two, three, and four distinct age classes, respectively, did not differ greatly. We chose the model with three age classes (1,2, and $\geq 3 \mathrm{yr}$ ) to generate survival estimates for our MHI Leslie matrix as it provided somewhat more complexity than the top ranked model while negligibly reducing support $\left(\Delta \mathrm{AIC}_{\mathrm{c}}=0.3\right)$. Survival estimates from this model are presented in Table 3. The observed proportion of pups that were known to have survived from birth to weaning was 0.93. Finally, Baker and Thompson (2007) reported senescent monk seal survival beginning after approximately the 16th year of age. However, the oldest known-aged MHI seal in our analysis was only $11 \mathrm{yr}$ old. Therefore, to avoid positive bias in survival of older age classes in our MHI modeling, we created a composite data set composed of MHI rates (from Table 2) up until age $16 \mathrm{yr}$, and Laysan Island rates from age 16 to $30 \mathrm{yr}$ (cf. Harting 2002). Further, the Siler competing risk model parameters governing senescent decline were fixed at the values fitted for NWHI seals. 
Table 3. Age-specific survival $\left(\Phi_{i}\right)$ and capture probability $(p)$ estimates from selected model in Table 2 for 76 Hawaiian monk seals in the main Hawaiian Islands. Standard error (SE) and lower (LCL) and upper (UCL) limits of $95 \%$ confidence intervals are shown.

\begin{tabular}{lcccc}
\hline \hline Parameter & Estimate & SE & LCL & UCL \\
\hline$\Phi_{1}$ & 0.771 & 0.054 & 0.650 & 0.859 \\
$\Phi_{2}$ & 0.863 & 0.061 & 0.697 & 0.945 \\
$\Phi_{3+}$ & 0.943 & 0.023 & 0.878 & 0.974 \\
$p^{\prime} 89-' 96$ & 1.000 & 0.000 & 1.000 & 1.000 \\
$p^{\prime} 97-00$ & 0.328 & 0.123 & 0.140 & 0.594 \\
$p^{\prime} 01-08$ & 0.875 & 0.027 & 0.813 & 0.919 \\
\hline
\end{tabular}

The proportion of female seals that had attained adult size varied with age and location. A model was fitted with age as a covariate and a five-level location effect (MHI plus four NWHI regions). Separate locations for the NWHI included French Frigate Shoals, Laysan Island, Lisianski Island, and a fourth group made up of the three western atolls combined (Pearl and Hermes, Midway, and Kure). MHI females tended to attain adult size at a significantly younger age than at two of the NWHI sites (French Frigate Shoals, $P<0.001$; Lisianski, $P=0.01$ ). No statistically significant difference was found between MHI and the other two NWHI sites; however, the sample size for MHI was very small. Still, all 6-yr-old females observed in the MHI were adult size compared to about $80 \%$ at Laysan Island and the western three atolls (Fig. 2).

MHI reproductive rates were estimated from observations of 29 known-aged females who gave birth to 17 pups during 1989-2008. Because the seals' attainment of adult size in the MHI was not significantly different from the pattern observed at Laysan Island, reproductive rate data for older females from the latter site were combined with the MHI observations to fit a plausible full reproductive curve for the MHI in life table analysis and population projection (Fig. 3).

The life tables constructed from the age-specific survival and reproductive rates for all seven sites (six NWHI breeding sites and MHI), were analyzed and used for population projections. The intrinsic growth rates $(\lambda)$ for all six NWHI sites were below 1.0, while that of the MHI was 1.065 (Table 4). Although these $\lambda$ values indicate the probable trajectory of each subpopulation at the theoretical stable age distribution, population projections are necessary to elucidate the influence that current age structures have on that outcome. Each NWHI subpopulation was projected separately, but their abundances were summed for presentation (Fig. 4). The NWHI projections indicated that the initial populations of 914 seals would decline to less than 250 seals in $20 \mathrm{yr}$. In contrast, the MHI population increased to slightly more than 400 seals in that time frame. The abundance of the two projected populations is therefore expected to be equal in approximately $15-16 \mathrm{yr}$.

\section{DISCUSSION}

Our results indicate that Hawaiian monk seal vital rates are much more favorable in MHI than in NWHI. Because this conclusion has rather profound implications for the future conservation of the species, we must carefully consider uncertainty in all components of the analysis. We generally have a high degree of confidence in 


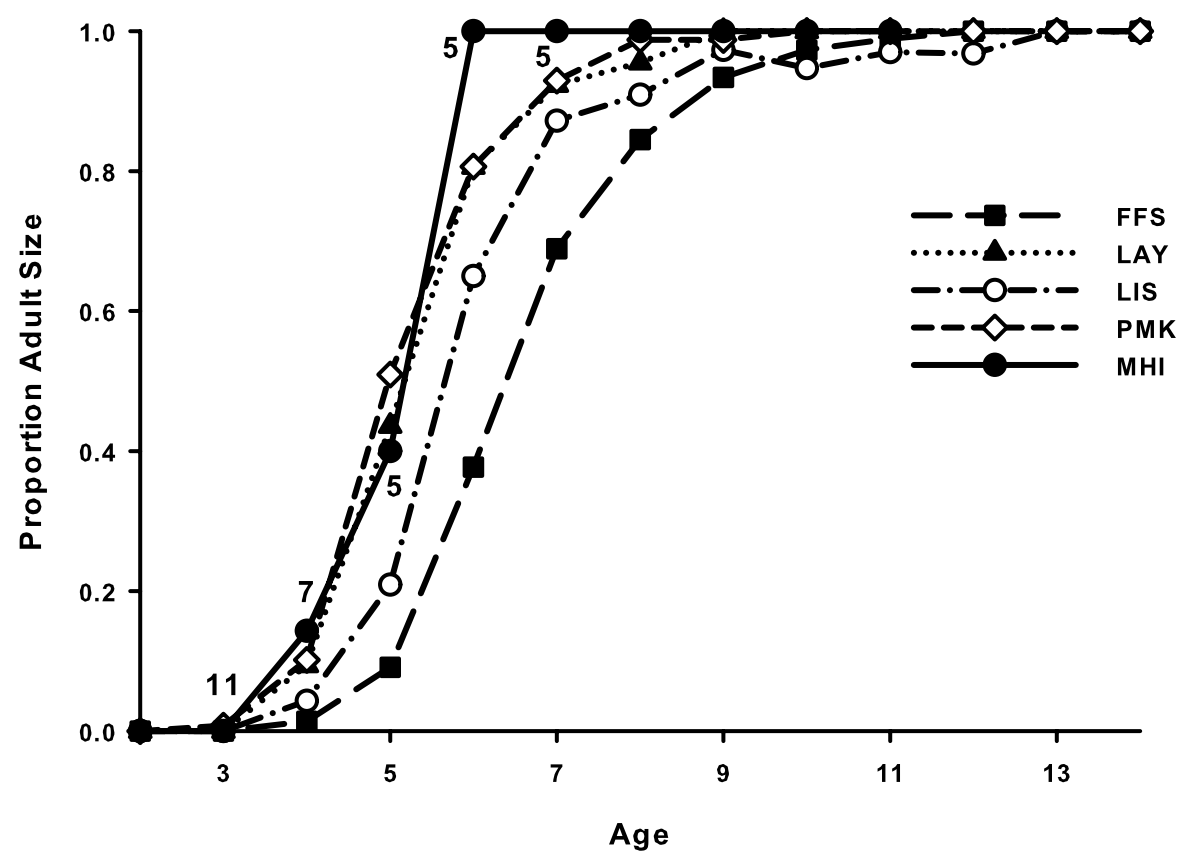

Figure 2. Proportion of female Hawaiian monk seals by age, which were adult size in the main Hawaiian Islands and at four Northwestern Hawaiian Islands areas, 1990-2008. Sample sizes of young known-aged females in the main Hawaiian Islands during this period are indicated. Locations are abbreviated as follows: FFS (French Frigate Shoals), LAY (Laysan Island), LIS (Lisianski Island), PMK (Pearl and Hermes, Midway and Kure combined), and MHI (main Hawaiian Islands).

the NWHI data and demographic parameter estimates. NWHI survival estimates are based on tagging nearly all the pups born and monitoring them throughout their lives with very high annual resight probabilities (Baker and Thompson 2007). Abundance and age-sex structures are also quite well known as subpopulations are largely enumerated in most years (Baker 2004, Baker et al. 2006a). More uncertainty surrounds NWHI reproductive rates as these are directly estimated for only three of the six main subpopulations and because annual variability is substantial (Harting et al. 2007). Nevertheless, much of the uncertainty in the NWHI vital rates is reflected in the range of realized projections from the stochastic simulation model (Harting 2002, Fig. 4).

In contrast, we are far less confident in our MHI data and estimates. Having no reliable estimate of total abundance, we assumed a starting abundance of 152 seals for our projections. This is likely a conservative value considering that our very limited surveillance still identified 113 individuals. The starting abundance does not affect conclusions about the intrinsic rate of population growth but will influence the abundance projections. Likewise, lacking any reliable basis for a starting age distribution, we simply used the stable age distribution from the fitted MHI Leslie matrix but acknowledge that the age distribution of this growing population is likely to depart from the theoretical distribution. Such deviations introduce some uncertainty in the transient dynamics of the trajectory, but in any case the population would be 


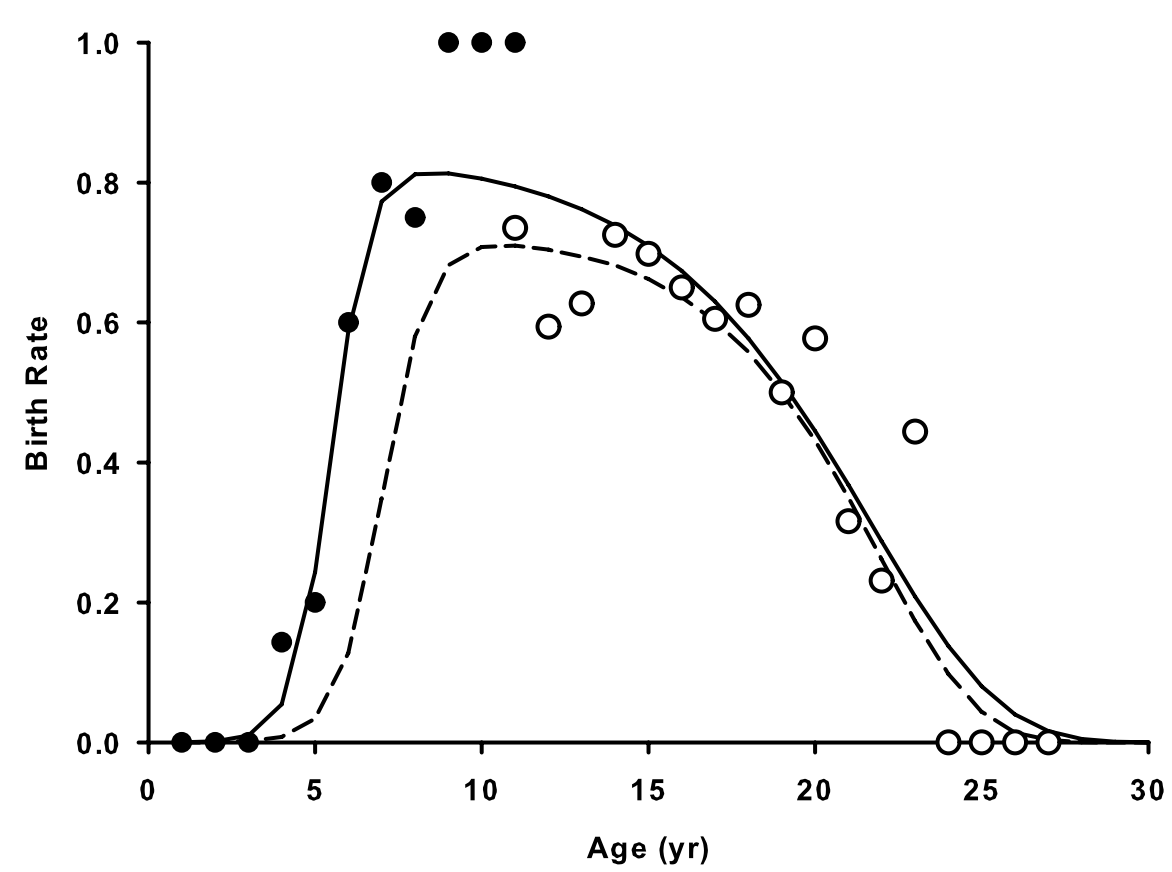

Figure 3. Observed and fitted reproductive rates for the main Hawaiian Islands (MHI). Closed circles are MHI observations (single observation for an age 11 female is displayed, but was not used for fitting curve). Open circles are Laysan Island observations. The MHI curve (solid line) was derived by fitting Equation 1 to the composite sample from both sites. The Laysan Island curve (dashed line) is shown for comparison.

exhibiting positive growth. Although sample sizes are admittedly somewhat meager, the MHI survival estimates are based on robust methods, have fairly narrow confidence intervals (Table 3), and there is no reason to suspect positive bias. We are therefore confident that juvenile survival has indeed been considerably higher in the MHI than in the NWHI. This is consistent with pups exhibiting far better body

Table 4. Intrinsic population growth rates $(\lambda)$ of Hawaiian monk seals at six Northwestern Hawaiian Islands subpopulations and the main Hawaiian Islands. Means and standard deviations $(s)$ for $\lambda$ are derived by random sampling (1,000 simulations) of demographic parameters from their fitted distributions.

\begin{tabular}{lc}
\hline \hline Subpopulation & $\lambda(\mathrm{s})$ \\
\hline Northwestern Hawaiian Islands & \\
French Frigate Shoals & $0.893(0.022)$ \\
Laysan Island & $0.891(0.019)$ \\
Lisianski Island & $0.956(0.027)$ \\
Pearl and Hermes Reef & $0.935(0.019)$ \\
Midway Atoll & $0.926(0.015)$ \\
Kure Atoll & $0.947(0.022)$ \\
Main Hawaiian Islands & $1.065(0.031)$ \\
\hline
\end{tabular}




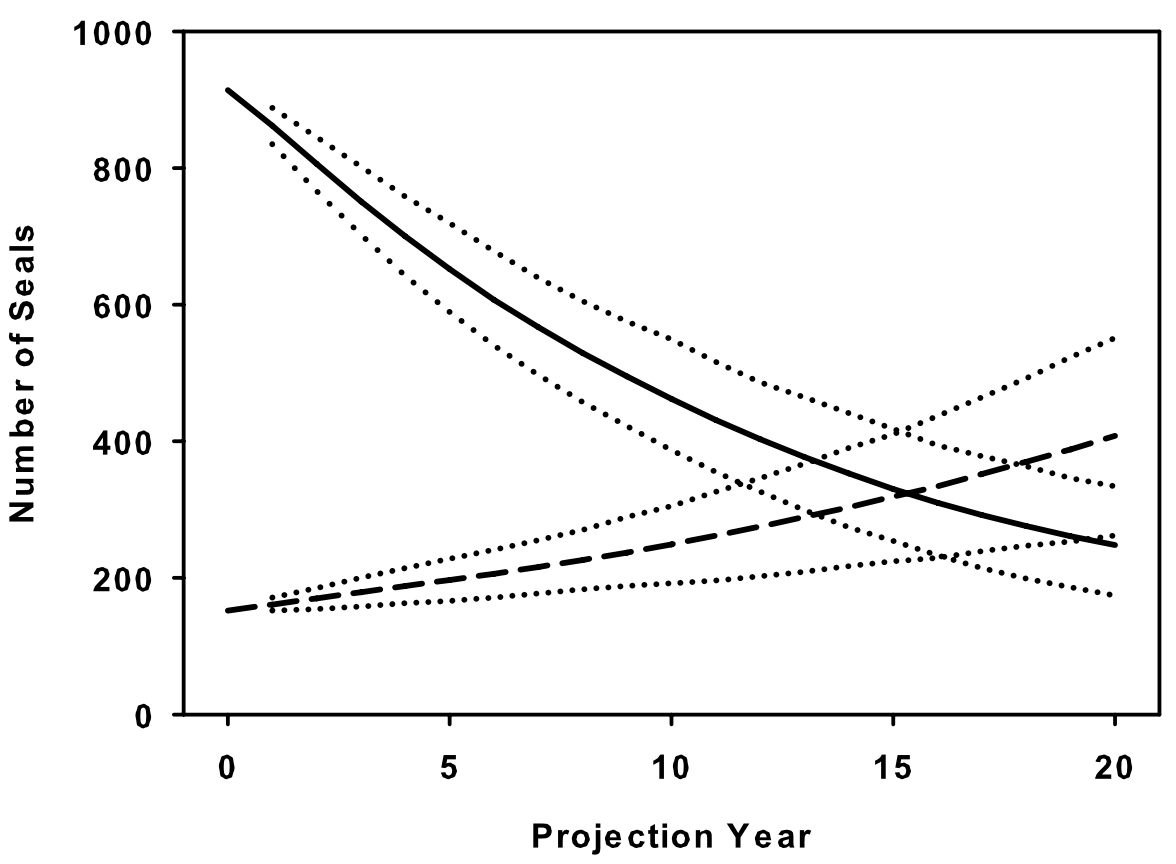

Figure 4. Population projections $(20 \mathrm{yr}$ ) for Northwestern Hawaiian Islands (NWHI) and main Hawaiian Islands monk seal subpopulations. The six NWHI subpopulations were projected separately, and results were summed for display.

condition (girth and length) at weaning in the MHI (Baker and Johanos 2004) and a strong relationship between weaning condition and first-year survival (Craig and Ragen 1999, Baker 2008). The regional differences in survival are especially evident in survival-to-age $(l x)$ curves (Fig. 5).

Our characterization of MHI reproductive rates is provisional but likely conservative. We only have reproductive information for 29 females spanning just the early portion of their reproductive ages. These pupping rate data could be subject to either positive or negative observation bias based on incomplete surveillance. The fact that MHI females grow to adult size at least as rapidly as those at Laysan suggests that using data from the latter site for the $\geq 11 \mathrm{yr}$ old portion of the MHI curve is appropriate. The higher observed birth rates among females $\leq 11 \mathrm{yr}$ old in the MHI arguably suggests the curve might be elevated among older animals compared to Laysan Island as well.

In summary, we acknowledge multiple sources of uncertainty, especially in the MHI input data, including survival of older seals, reproductive rates of older females, current population size, and age distribution. However, we have endeavored to make conservative adaptations in each case.

We think that the previously suggested reasons for MHI population growth (i.e., low intra- and interspecific competition) remain valid (Baker and Johanos 2004). Large predatory fish are far more abundant in the NWHI than in the MHI (Friedlander and DeMartini 2002), and these fish directly compete with foraging monk seals (Parrish et al. 2008). One might speculate that mortality from large 


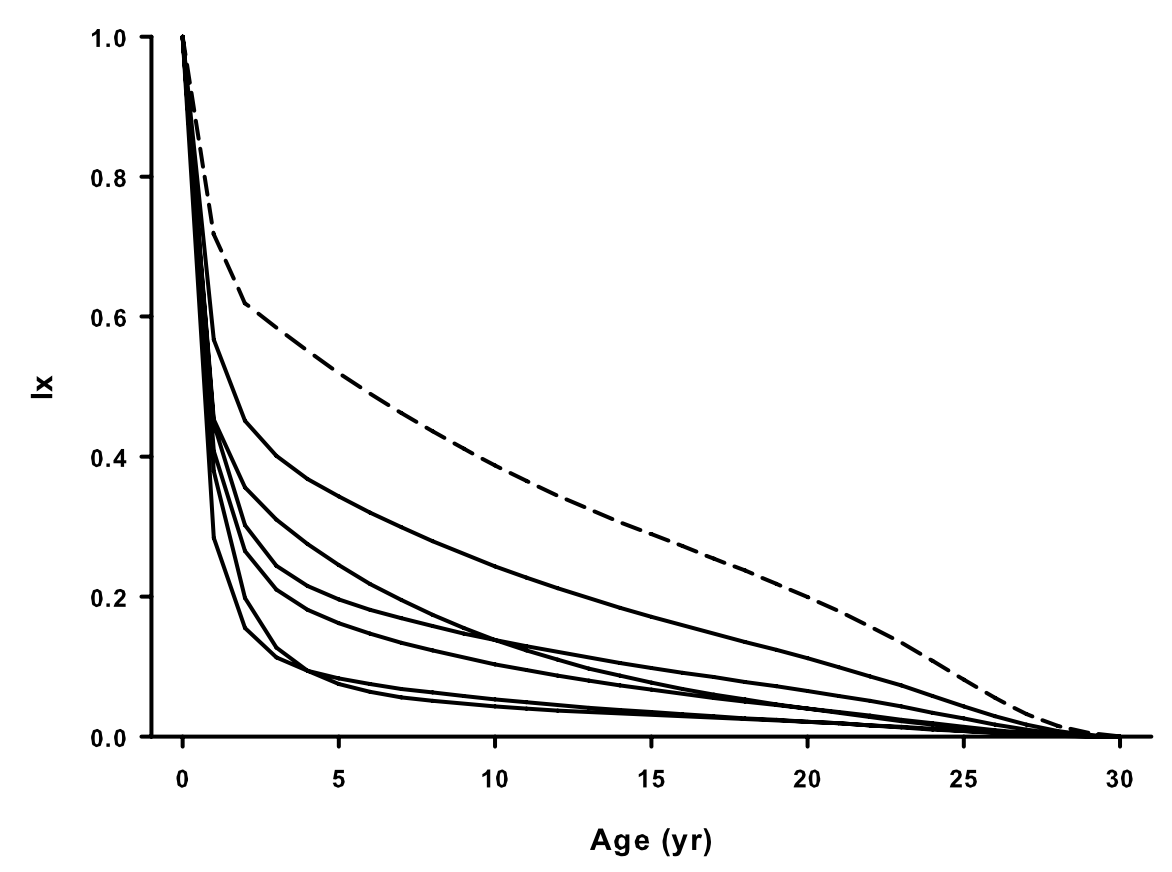

Figure 5. Cumulative survival probability curves $(l x)$ for the six Northwestern Hawaiian Islands subpopulations (solid lines), based upon recent (2006-2008) rates, and all available data in the main Hawaiian Islands (dashed lines).

shark predation on seals in the NWHI (Bertilsson-Friedman 2006) may likewise be lower in the MHI, though this has not been formally evaluated. Migration from the NWHI does not appear to have significantly influenced MHI population growth. Since consistent seal tagging began in the early 1980s, we have only documented five seals that swam from the NWHI to the MHI.

Thus far, we have discussed uncertainty in our estimates of current population status and vital rates. More pertinent with regard to anticipating future scenarios is how these parameters will change. The 20 -yr population projections (Fig. 4) were conducted using stochastic sampling with error of MHI values to date and of recent rates in NWHI. How might these trends change in the coming years?

Unfortunately, although there are limits to how much rates can improve (survival cannot exceed 1 and there are likewise physiological limits on reproduction), mortality events and reproductive failures are far less constrained. Indeed, the history of Hawaiian monk seal conservation is replete with unforeseen catastrophic events, including unexplained die-offs, reproductive females killed by aggressive male seals (Hiruki et al. 1993), and pups being heavily preyed upon by sharks in localized areas (Harting, unpublished observations). The MHI appears to be steadily growing in abundance from an initially very low level. Similar recoveries of monk seal subpopulations have been observed in the NWHI, most notably at French Frigate Shoals, where the population grew rapidly from the early 1960s to the late 1980s (Gerrodette and Gilmartin 1990). This subpopulation has subsequently crashed as a result of increased juvenile mortality, possibly due to exceeding carrying capacity (Craig and 
Ragen 1999). The monk seal carrying capacity of the MHI is unknown. For reasons that are largely uncertain, conditions in most of the NWHI have not been favorable to monk seals for at least a decade. Polovina et al. (2008) found that areas of low oceanic productivity have been expanding worldwide, including the North Pacific subtropical gyre, in which the Hawaiian archipelago is located. Polovina et al. (2008) further suggest that this trend is likely to continue with further global warming. Thus, although we can hope for a reversal of fortune as has occurred in the past, we must realistically plan for a prolonged period of adverse conditions in the NWHI. Regardless of any improvement in extrinsic conditions, the current age structures of NWHI subpopulations are so unfavorable that further declines in abundance for approximately the next decade are highly likely.

Thus, despite uncertainties, our most informed prediction is that the NWHI seal populations will continue to dwindle while MHI seals become more plentiful, resulting in a far more even distribution of the species among these regions. This leads to two broad conclusions about how conservation of monk seals should change in the near future.

First, all efforts should be pursued to reduce the rate of decline in the NWHI. The recent Recovery Plan for Hawaiian monk seals prescribes several approaches to reducing juvenile mortality, including mitigating shark predation and reducing entanglement in marine debris. Further, the Plan calls for improving juvenile survival through a variety of interventions (e.g., translocations, nutritional support, Baker and Littnan 2008). The focus of these efforts is on improving currently poor juvenile survival, which Harting (2002) identified as having the greatest influence on the population growth rate. Less immediate but perhaps just as serious a hazard is terrestrial habitat loss in the low-lying NWHI because of sea-level rise (Baker et al. 2006b). This threat needs to be better characterized and mitigation measures developed as feasible.

Second, while the MHI monk seals appear to be thriving at the moment, more conservation resources are needed to prepare for the challenges associated with increasing abundance of seals in the near future. Threats to seals in the MHI are largely distinct from those constraining the NWHI populations. Interactions between seals and people on beaches and in nearshore waters are growing, resulting in the disturbance and harassment of seals and occasional injuries to humans. In 2009, three seals, including a pregnant female, were found shot to death in the MHI. Fishery interactions, including seal hookings and drowning in gillnets, are becoming more common (Carretta et al., in press). Seals in the MHI are also exposed to diseases they have never encountered before, through contact with domestic and feral mammals and their waste (Littnan et al. 2006). Federal, state, and local authorities in the MHI are currently struggling to manage these seal-related issues. As the seal population grows, we can only expect conflicts to intensify, most likely to the detriment of individual seals.

\section{ACKNOWLEDGMENTS}

We are especially grateful for the efforts of numerous volunteer monk seal responders; without them our understanding of main Hawaiian Islands monk seals would be greatly diminished. We thank the U.S. Coast Guard for their support of aerial surveys. E. Moreland made significant contributions to building a network of volunteers, recording sightings, and developing a computerized sightings and photographic identification database. Numerous partners also provided logistic, data collection, and other support in the main Hawaiian 
Islands, including the State of Hawaii, the NOAA Fisheries Pacific Islands Regional Office, the Hawaiian Islands Humpback Whale National Marine Sanctuary, the Kahoolawe Island Reserve Commission, Kalaupapa National Historic Park, city and county lifeguards, and others. This manuscript was improved by comments from Charles Littnan.

\section{LiTERATURE CiTED}

Anderson, D. R., K. P. Burnham and W. L. Thompson. 2000. Null hypothesis testing: Problems, prevalence, and an alternative. Journal of Wildlife Management 64:912923.

Antonelis, G. A., J. D. Baker, T. C. Johanos, R. C. Braun and A. L. Harting. 2006. Hawaiian monk seal (Monachus schauinslandi): Status and conservation issues. Atoll Research Bulletin 543:75-101.

Baker, J. D. 2004. Evaluation of closed capture-recapture methods to estimate abundance of Hawaiian monk seals, Monachus schauinslandi. Ecological Applications 14:987-998.

Baker, J. D. 2008. Variation in the relationship between offspring size and survival provides insight into causes of mortality in Hawaiian monk seals. Endangered Species Research 5:55-64.

Baker, J. D., and T. C. Johanos. 2004. Abundance of the Hawaiian monk seal in the main Hawaiian Islands. Biological Conservation 116:103-110.

Baker, J. D., and P. M. Thompson. 2007. Temporal and spatial variation in age-specific survival rates of a long-lived mammal, the Hawaiian monk seal. Proceedings of the Royal Society B 274:407-415.

Baker J. D., and C. L. Littnan. 2008. Report of the Hawaiian Monk Seal Captive Care Workshop, Honolulu, Hawaii, 11-13 June 2007. Pacific Islands Fisheries Science Center Administrative Report H-08-02 (unpublished). 42 pp. Available from Pacific Islands Fisheries Science Center, 2570 Dole Street, Honolulu, HI 96822-2396.

Baker J. D., C. L. Littnan and D. W. Johnston. 2006a. Potential effects of sea-level rise on the terrestrial habitats of endangered and endemic megafauna in the Northwestern Hawaiian Islands. Endangered Species Research 4:1-10.

Baker J. D., A. L. Harting and T. C. Johanos. 2006b. Use of discovery curves to assess abundance of Hawaiian monk seals. Marine Mammal Science 22:847-861.

Bertilsson-Friedman, P. 2006. Distribution and frequencies of shark-inflicted injuries to the endangered Hawaiian monk seal (Monachus schauinslandi). Journal of Zoology 268:361368.

Carretta, J. V., K. A. Forney, M. S. Lowry, J. Barlow, J. Baker, D. Johnston, B. Hanson, R. L. Brownell Jr., J. Robbins, D. K. Mattila, K. Ralls, D. Lynch and L. Carswell. 2010. U.S. Pacific marine mammal stock assessments: 2009. U.S. Department of Commerce, NOAA Technical Memorandum, NOAA-TM-NMFS-SWFSC-453. $336 \mathrm{pp}$.

Craig, M. P., and T. J. Ragen. 1999. Body size, survival, and decline of juvenile Hawaiian monk seals, Monachus schauinslandi. Marine Mammal Science 15:786-809.

Friedlander, A. M., and E. E. Demartini. 2002. Contrasts in density, size, and biomass of reef fishes between the Northwestern and the main Hawaiian islands: The effects of fishing down apex predators. Marine Ecology Progress Series 230:253-264.

Gerrodette, T., and W. G. Gilmartin. 1990. Demographic consequences of changed pupping and hauling sites of the Hawaiian monk seal. Conservation Biology 4:423-430.

Gilmartin, W. G. 1983. Recovery plan for the Hawaiian monk seal, Monachus schauinslandi. In cooperation with the Hawaiian Monk Seal Recovery Team. U.S. Department of Commerce, NOAA Technical Report. 29 pp.

Harting, A. L. 2002. Stochastic simulation model for the Hawaiian monk seal. Ph.D. thesis, Montana State University, Bozeman, MT. 328 pp.

Harting, A. L., J. D. Baker and T. C. Johanos. 2007. Reproductive patterns of the Hawaiian monk seal. Marine Mammal Science 23:553-573. 
Hiruki, L. M., I. Stirling, W. G. Gilmartin, T. C. Johanos and B. L. Becker. 1993. Significance of wounding to female reproductive success in Hawaiian monk seals (Monachus schauinslandi) at Laysan Island. Canadian Journal of Zoology 71:469-474.

Jolly, G. M. 1965. Explicit estimates from capture-recapture data with both death and immigration-stochastic model. Biometrika 52:225-247.

Juvik, S. P., and J. O. Juvik. 1998. Atlas of Hawaii. University of Hawaii Press, Honolulu, HI.

Littnan, C. L., B. S. Stewart, P. K. Yochem and R. Braun. 2006. Survey for selected pathogens and evaluation of disease risk factors for endangered Hawaiian monk seals in the main Hawaiian Islands. EcoHealth 3:232-244.

NOAA, (National Oceanic and Atmospheric Administration). 2001. Hawaii ESI: ESI (Environmental Sensitivity Index Shoreline Types-Polygons and Lines). Second edition. National Ocean Service, Office of Response and Restoration, Hazardous Materials Response Division, Seattle, WA.

NMFS, (National Marine Fisheries Service). 2007. Recovery plan for the Hawaiian monk seal (Monachus schauinslandi). Second Revision. U.S. Department of Commerce, National Marine Fisheries Service, Silver Spring, MD. 165 pp.

Parrish, F. A., G. J. Marshall, B. Buhleier and G. A. Antonelis. 2008. Foraging interaction between monk seals and large predatory fish in the Northwestern Hawaiian Islands. Endangered Species Research 4:299-308.

Peterson, G. D., G. S. Cumming and S. R. Carpenter. 2003. Scenario planning: A tool for conservation in an uncertain world. Conservation Biology 17:358-366.

Polovina, J. J., E. A. Howell and M. Abecassis. 2008. Ocean's least productive waters are expanding. Geophysical Research Letters 35:2-6.

Seber, G. A. F. 1965. A note on the multiple recapture census. Biometrika 52:249-259.

Siler, W. 1979. A competing-risk model for animal mortality. Ecology 60:750-757.

Siler, W. 1983. Parameters of mortality in human populations with widely varying life spans. Statistics in Medicine 2:373-380.

White, G. C., and K. P. Burnham. 1999. Program MARK: Survival estimation from populations of marked animals. Bird Study 46(Suppl.):120-138.

Received: 6 August 2009

Accepted: 26 February 2010 